\title{
Seismic Upgrading of Reinforced Concrete School Buildings
}

\author{
Mohamed S. Issa, and Heba M. Issa \\ Reinforced Concrete Institute, Housing and Building National Research Center, Giza, Egypt. \\ (Corresponding author: Drmsisssa@gmail.com)
}

\begin{abstract}
This paper evaluates the seismic behavior of four methods for retrofitting typical reinforced concrete school building. The original school (SO) suffers from limited ductility and lateral resistance. The four seismic upgrading methods are using carbon fiber reinforced polymers (SUFRP), steel jacket (SUSJ), bracing (SUBR), or concrete jacket (SUCJ). Nonlinear pushover and time history analyses are made for the five schools. Three code-scaled natural earthquakes are utilized for the inelastic response history analysis. The pushover analysis revealed that providing the school with bracing (SUBR) results in reducing the lateral displacements. However, the three other types of seismic retrofit (SUFRP, SUSJ, and SUCJ) develop larger lateral displacements when compared to the original school (SO). The translation ductility and energy dissipation for school SUBR is poor while they are good for schools SUFRP, SUSJ, and SUCJ. The base shear is increased for the four upgrading methods (SUFRP, SUSJ, SUBR, and SUCJ) compared to school SO. From the nonlinear time-history analysis, the maximum interstorey drift was approximately similar for schools SO, SUFRP, and SUCJ. Lesser values for the maximum interstorey drift are obtained for schools SUSJ and SUBR. The nonlinear time-history analysis also gives similar base shear for all the upgrading methods compared to school SO with the exception of school SUCJ which showed increase in the base shear.
\end{abstract}

Keywords: Seismic upgrading, jackets, retrofitting, pushover analysis, time history analysis.

\section{Introduction}

A considerable number of buildings all around the world are designed for gravity loads only or according to old building codes with smaller seismic loads than the current codes. These buildings suffer from inadequate seismic details and lateral resistance. Therefore, it is important to enhance their seismic behavior using different methods.

Adhikari et al. (2019) performed finite element analysis to study the seismic non-linear behavior of nine reinforced concrete buildings. They compared the inter-story drifts, capacity curves, and strengths. Also, they evaluated the vulnerability of the nine buildings. They jacketed the columns of the vulnerable buildings and performed a finite element analysis. The conclusion is that jacketing columns improves the seismic behavior. Gandelli et al. (2019) retrofitted a hospital using dissipative braces. They performed non-linear time history analysis which confirmed that the system protects both the nonstructural components and the structural frame. Porcu et al. (2019) performed time-history analysis to study the behavior of seismically upgraded building using carbon fiber reinforced polymers. They used two programs (SAP2000 and SeismoStruct) and compared the differences in the modeling. Elbetar and Issa (2017) performed pushover analysis to evaluate three seismic retrofit systems for two dimensional frames. They found that for low rise frames, upgrading the columns using concrete or steel jackets is effective in improving the seismic behavior. Almeida et al. (2017) utilized buckling restrained braces to seismically upgrade school building. They performed dynamic and static analyses to study this retrofitting system. They also suggested a design method to minimize the dimensions of the braces. The minimized bracing system resulted in high energy dissipation and strength. Issa and Taha (2015) conducted pushover and response history analyses to evaluate three types of seismic enhancement bracing systems. They reported that the three bracing systems are efficient in upgrading the seismic behavior. Choi et al. (2014) presented a method for seismic upgrade of the columns of reinforced concrete frames which are deficient in shear using FRP jackets. Genetic algorithm is used to optimize the cost of FRP jacketing and the seismic performance. They applied their method to 3-story reinforced concrete frame. Using this algorithm, they reduced the variation of inter-story drift in the same time prevented the shear failure while minimizing the used FRP. Sarno and 
Manfredi (2010) performed seismic evaluation of framed reinforced concrete building which suffers from low ductility and lateral resistance. They upgraded the building using buckling restrained braces which dissipate the earthquake energy. To evaluate the new system, they performed pushover and time history analyses. They found that local and global displacements are reduced and the ductility is enhanced. Thermou and Elnashai (2006) discussed the effect of different seismic repair methods on the member and system performance. They commented on both foundation and super-structure upgrading methods. Their discussion covered the effect of upgrading methods on the ductility, strength, and stiffness. Maheri (2005) presented a method for seismic upgrade of reinforced concrete frames by applying fiber-reinforced composite either as wet or as sheets to the reinforced concrete members. He compared the ductility and strength of such upgraded building with other methods of seismic upgrade such as steel and FRP jackets and steel bracing. Maheri (2005) reported that applying the fiber-reinforced composite is suitable for undamaged and damaged reinforced concrete members as the ductility, stiffness, and strength are all increased. Griffith and Pinto (2000) presented seismic test of 4-story reinforced concrete frame with infill walls. The frame is of weak-column strong-beam type. Based on the results and on the survey of literature, they suggested three seismic retrofit schemes which are to be tested in a later research. The seismic upgrading methods are:replacing the infill walls by damping braces, jacketing some of the unreinforced masonry walls and columns, and jacketing the column hinge zones. Rodriguez et al. (1991) reviewed the literature on seismic upgrade of reinforced concrete buildings. They covered the analytical and experimental work with emphasis on columns repair.

\section{Aim and Research Significance}

The purpose of this research is to evaluate the behavior of a typical school building in the case of earthquake events and propose four upgrading methods. The merits of these methods are to be compared together.
3. Performing Linear Elastic Analysis to Design the Original School Building (SO)
The original school building (SO) of this research is designed for gravity loads only. The loads on the analyzed school building are the own weight of the reinforced concrete beams and columns, the own weight of $24 \mathrm{~cm}$ and $20 \mathrm{~cm}$ slab, floor cover of weight equals to $0.17 \mathrm{t} / \mathrm{m}^{2}$, line wall load equals to $1.11 \mathrm{t} / \mathrm{m}$, and live load equals equals to to $0.3 \mathrm{t} / \mathrm{m}^{2}$. The plane of the school is shown in Figure 1.0.

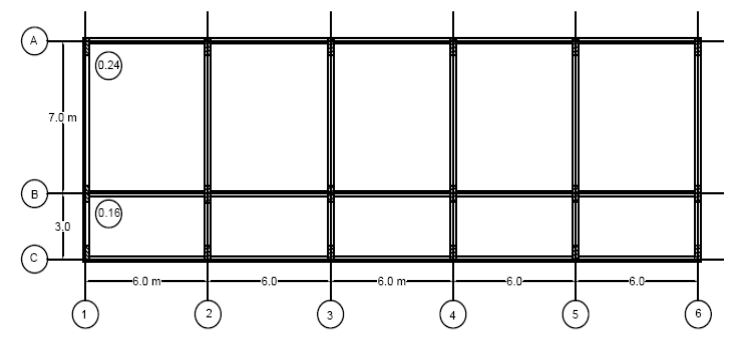

Figure 1- Plan of the Investigated School

\section{Investigated Original and Upgraded School Building}

The investigated original school (SO) consists of five bays in the long-direction (five class rooms) and two bays in the short-direction (the class room and the corridor) as shown in Figure 1.0. It consists of five floors each $3 \mathrm{~m}$ height with external steel stairs on the two sides which are not considered in the analysis. The structural system is formed of reinforced concrete solid slabs and reinforced concrete frames on axes 1, 2, 3, 4, 5, and 6 which are the short directions. The cross-sections and reinforcements are as given in Table 1.0. The material properties of the concrete and steel are given in Table 2.0. The original school (SO) is designed for gravity loads only.

To upgrade the seismic performance of the school, four retrofitting techniques are used. These are wrapping all the columns with fiber reinforced polymers (SUFRP), jacketing all the columns with steel (SUSJ), adding reinforced concrete bracing (SUBR), and jacketing all the columns with reinforced concrete (SUCJ).

\section{FRP Jacket:}

Three layers of carbon FRP are used. The thickness of each fiber layer is $0.165 \mathrm{~mm}$. The tensile strength of the fiber is $2600 \mathrm{MPa}$, the tensile modulus is $230000 \mathrm{MPa}$, the maximum elongation is $1.3 \%$, and the weight is $300 \mathrm{gm} / \mathrm{m}^{2}$. A FRP jacketed column is shown in Figure 2.0 .

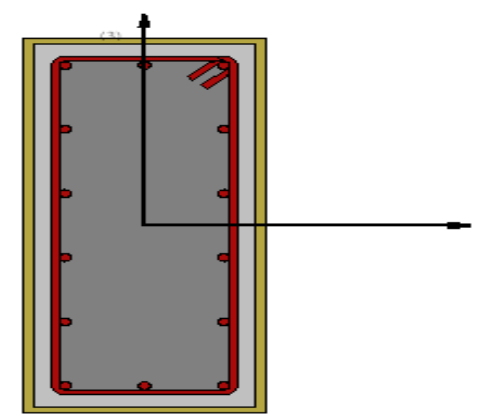

Figure 2- FRP Jacketed Column 


\section{Steel Jacket:}

This jacket is modelled indirectly as a $1 \mathrm{~cm}$ thickness concrete jacket. Stirrups of diameter $12 \mathrm{~mm}$ at 200 $\mathrm{mm}$ intervals are used to represent the steel plates on the four sides of the columns. Four bars at the corners of the columns of diameter $32 \mathrm{~mm}$ are equivalent to the corner angles. A steel jacketed column is shown in Figure 3.0 .

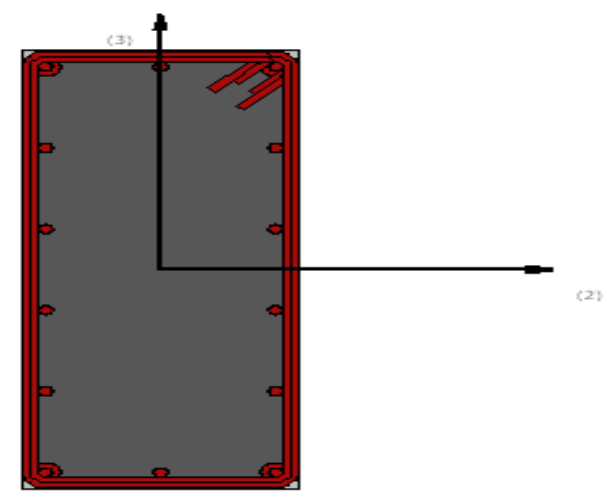

Figure 3- Steel Jacketed Column

\section{Bracing:}

$\mathrm{X}$-shaped reinforced concrete bracings are to be added on each floor on axis 1 between axes $\mathrm{A}$ and $\mathrm{B}$ and on axis 6 between axes $\mathrm{A}$ and $\mathrm{B}$. The crosssection and reinforcement of these bracings are as shown in Table 1.0. A braced school is shown in Figure 4.0 .

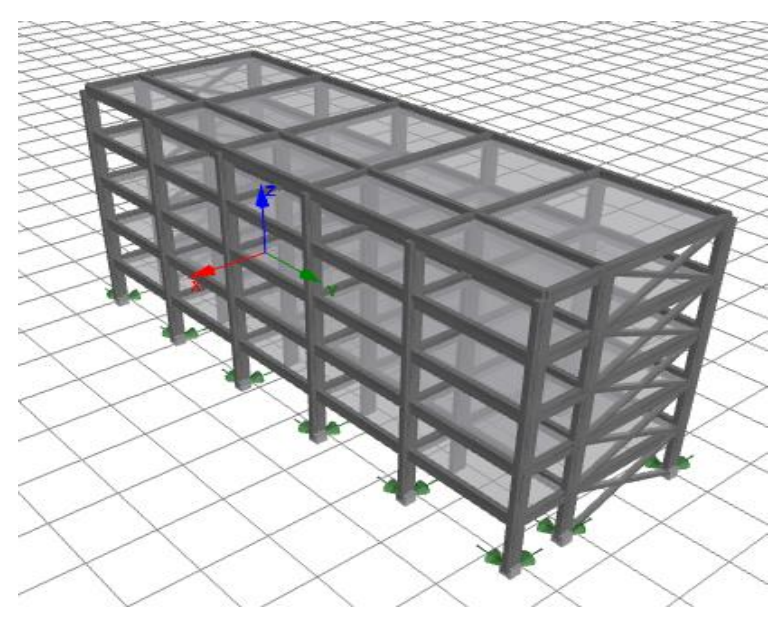

Figure 4- Braced School

\section{Reinforced Concrete Jacket:}

Reinforced concrete jacket of $15 \mathrm{~cm}$ thickness on all the four sides of the columns is used. The vertical reinforcing bars for the jacket are 18 bars of diameter $16 \mathrm{~mm}$ placed on the four sides. Stirrups of diameter $10 \mathrm{~mm}$ at $200 \mathrm{~mm}$ intervals are used. The strengths of the used concrete and reinforcement for the jacket are the same as the original columns. A reinforced concrete jacketed column is shown in Figure 5.0.

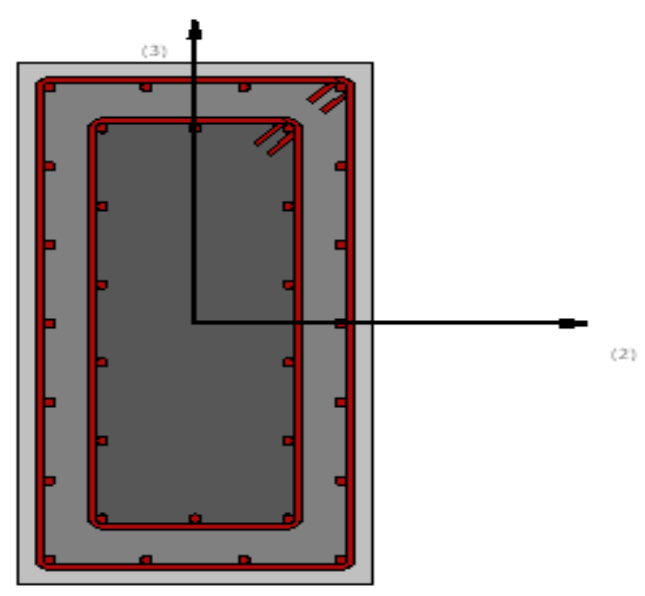

Figure 5- Reinforced Concrete Jacketed Column 
Table 1- Cross-Sections and Reinforcements for the Members of the Investigated School

\begin{tabular}{|c|c|c|c|}
\hline Item & Section-Cross & tReinforcemen & Stirrups \\
\hline Beam & $30 * 130 \mathrm{~cm}$ & $\begin{array}{c}\text { Bottom=top=8 bars diameter } 18 \mathrm{~mm} \\
\& \text { middle }=8 \text { bars diameter } 10 \mathrm{~mm}\end{array}$ & $\begin{array}{c}\text { Diameter } 10 \mathrm{~mm} \\
\text { at } 20 \mathrm{~cm}\end{array}$ \\
\hline Column & $30 * 140 \mathrm{~cm}$ & bars diameter $18 \mathrm{~mm} 16$ & $\begin{array}{c}\text { Diameter } 10 \mathrm{~mm} \\
\text { at } 20 \mathrm{~cm}\end{array}$ \\
\hline Bracing & $25 * 25 \mathrm{~cm}$ & bars diameter $16 \mathrm{~mm} 4$ & $\begin{array}{c}\text { Diameter } 10 \mathrm{~mm} \\
\text { at } 20 \mathrm{~cm}\end{array}$ \\
\hline
\end{tabular}

Table 2- Mechanical Properties of the Concrete and Steel of the Investigated School

\begin{tabular}{|c|c|}
\hline Property & Value \\
\hline 28-day cylinder compressive strength of concrete & $20 \mathrm{MPa}$ \\
\hline Elastic modulus of reinforcement & $2 * 10^{5} \mathrm{MPa}$ \\
\hline Yield strength of reinforcement & $420 \mathrm{MPa}$ \\
\hline
\end{tabular}

\section{Earthquake Records Used in the Nonlinear Dynamic Analyses (Acceleration Time History Analyses)}

The three earthquake records used in the time history analyses are shown in Table 3.0. The records are obtained from the documentations of the SeismoStruct program which in turn obtained them from the PEER Center (http://peer.berkeley.edu/smcat). These are accelerograms of real earthquakes which are to be matched to the response spectrum of the Egyptian loading code. The assumed damping is $5 \%$, the considered spectral acceleration is $0.3 \mathrm{~g}$ where $\mathrm{g}$ is the gravitational acceleration, the spectrum type is Type 1 , the ground type is $\mathrm{C}$, the importance coefficient is 1.20 , and the response reduction factor $(\mathrm{R})$ is 5.0 . The matching task is performed using a software titled SeismoMatch. Figure 6.0 gives an example for a matched response spectrum.

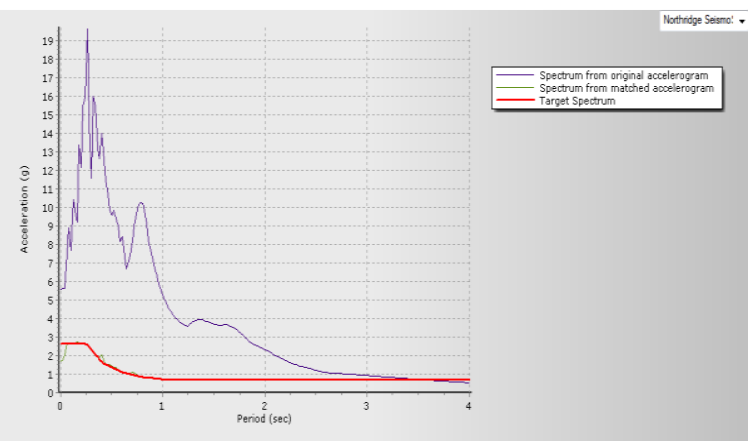

Figure 6- Original and Matched Spectrums of the Northridge Earthquake
Table 3.0: Utilized Earthquake

\begin{tabular}{|c|c|c|c|c|c|}
\hline & 続 & ڤี & 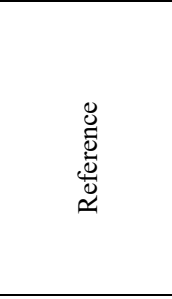 & 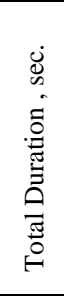 & $\begin{array}{c}\text { Maximum } \\
\text { Accel- } \\
\text { eration } \\
\text { Before } \\
\text { Matching } \\
\text { to Egyptian } \\
\text { Code } \\
\text { Response } \\
\text { Spectrum } \\
\end{array}$ \\
\hline 1 & Friuli & $\begin{array}{c}\text { May } \\
66 \\
1976\end{array}$ & $\begin{array}{c}\text { SeismoStruct } \\
\text { Program } \\
\text {-docum } \\
\text { entation, } 2014\end{array}$ & 36.3 & $0.10 \mathrm{~g}$ \\
\hline 2 & Hollister & $\begin{array}{c}\text { April } \\
\text { ،9 } \\
1961\end{array}$ & $\begin{array}{l}\text { SeismoStruct } \\
\text { Program } \\
\text {-docum } \\
\text { entation, 2014 }\end{array}$ & 39.9 & $0.12 \mathrm{~g}$ \\
\hline 3 & $\begin{array}{l}\text {-orthN } \\
\text { ridge }\end{array}$ & $\begin{array}{c}\text { Jan. } \\
\text { ‘17 } \\
1994\end{array}$ & $\begin{array}{c}\text { SeismoStruct } \\
\text { Program } \\
\text {-docum } \\
\text { entation, 2014 }\end{array}$ & 39.9 & $0.57 \mathrm{~g}$ \\
\hline
\end{tabular}

\section{Modeling of the Investigated School}

Both types of analysis are made using a software titled SeismoStruct. This is a finite element program which accounts for material and geometric nonlinearities. The solver of the program subdivides the loading increments based on the convergence difficulties. Thus, it is stable and accurate. The members are modeled as force-based frame elements. The sections are subdivided into fibers. The concrete is modeled using a nonlinear model of constant confinement. The constitutive relationship and the confinement of stirrups follow the method of Mander et al. (1988). The cyclic rules adopted for concrete are those of Martinez-Rueda and Elnashai (1997). The reinforcement is modeled assuming a bilinear material behavior. 


\section{Performed Nonlinear Structural Analysis:}

The seismic behavior of the original school (SO) and the four upgrading systems (SUFRP, SUSJ, SUBR, and SUCJ) is studied through both static pushover analysis and dynamic time history analysis.

\section{A-Nonlinear Static Pushover Analysis:}

Static pushover analysis is performed by applying uniform loads in the short horizontal-direction of the school to evaluate its inelastic behavior and obtain seismic response parameters. The top displacement divided by the total height at failure increased noticeably for upgrading method SUCJ and reduced noticeably for upgrading method SUBR as shown in Table 4.0. The maximum interstorey drift divided by the storey height at failure reduced for retrofitting systems SUSJ and SUCJ with noticeable reduction for SUBR. For example, the top displacement divided by the total height at failure for the original school SO is $12.14 * 10^{-3}$. This value increased to $17.2 * 10^{-3}$ for retrofitted school SUCJ and reduced to $2.9 * 10^{-3}$ for retrofitted school SUBR. The maximum interstory drift divided by the storey height which occurs for the $1^{\text {st }}$ level at failure is $36.5 * 10^{-3}$ for school SO. This value reduced to $31.1 * 10^{-3}$ for school SUCJ and reduced to $4.1 * 10^{-3}$ for school SUBR. We should notice that the failure loads are different for the five schools as shown by the capacity curves of Figure
7.0. The exact values of the base shears are shown in Table 5.0. All the four methods resulted in increase of the base shear with the maximum increase recorded for school SUCJ and the lowest increase recorded for school SUFRP. Table 6.0 shows the seismic parameters obtained from the static pushover analysis. These parameters are defined in Issa and Issa, 2015. The parameter $\Omega$ (overstrength factor) equals the base shear at general yield point $\left(\mathrm{V}_{\mathrm{y}}\right)$ divided by the base shear at formation of the first plastic hinge $\left(\mathrm{V}_{\mathrm{s}}\right)$ while the parameter $\mu_{\mathrm{s}}$ (structural ductility) equals the maximum drift $\left(\Delta_{\max }\right)$ divided by the drift at general yield $\left(\Delta_{\mathrm{y}}\right)$. Both parameters increased for retrofitting systems SUSJ which means better translation ductility. For SUBR, however, the two parameters are reduced compared to the unretrofitted school, SO, which indicates lower translation ductility. The parameter $\mathrm{q}$ is the behavior factor which is the ratio between the theoretical maximum elastic base shear $\left(\mathrm{V}_{\mathrm{eu}}\right)$ and the allowable working design shear. The value of this parameter increased for the retrofitted schools SUFRP, SUSJ, and SUCJ which means that they are more dissipative for earthquake energy. However, for the upgraded school SUBR the "q" parameter is little reduced. 

Table 4.0: Lateral Drifts of the Investigated School from Pushover Analysis at Failure

\begin{tabular}{|c|c|c|c|c|c|}
\hline \multirow[t]{2}{*}{ Lateral Drifts } & \multicolumn{5}{|c|}{ Building } \\
\hline & $\mathrm{SO}$ & SUFRP & SUSJ & SUBR & SUCJ \\
\hline $\begin{array}{l}\text { Top displacement/ total height } \\
\text { (Total displacement ratio) }\end{array}$ & ${ }^{3-} 10 * 12.14$ & ${ }^{3-} 10 * 12.15$ & ${ }^{3-} 10 * 12.70$ & ${ }^{3-} 10 * 2.90$ & ${ }^{3-} 10 * 17.20$ \\
\hline $\begin{array}{l}\text { Interstorey drift/ storey height } \\
\text { at } 1^{\text {st }} \text { level } \\
\text { (Maximum value for all the } \\
\text { levels) } \\
\text { (story drift ratio-inter) }\end{array}$ & ${ }^{3-} 10 * 36.5$ & ${ }^{3-} 10 * 36.1$ & ${ }^{3-} 10 * 23.3$ & ${ }^{3-} 10 * 4.1$ & ${ }^{3-} 10 * 31.1$ \\
\hline
\end{tabular}

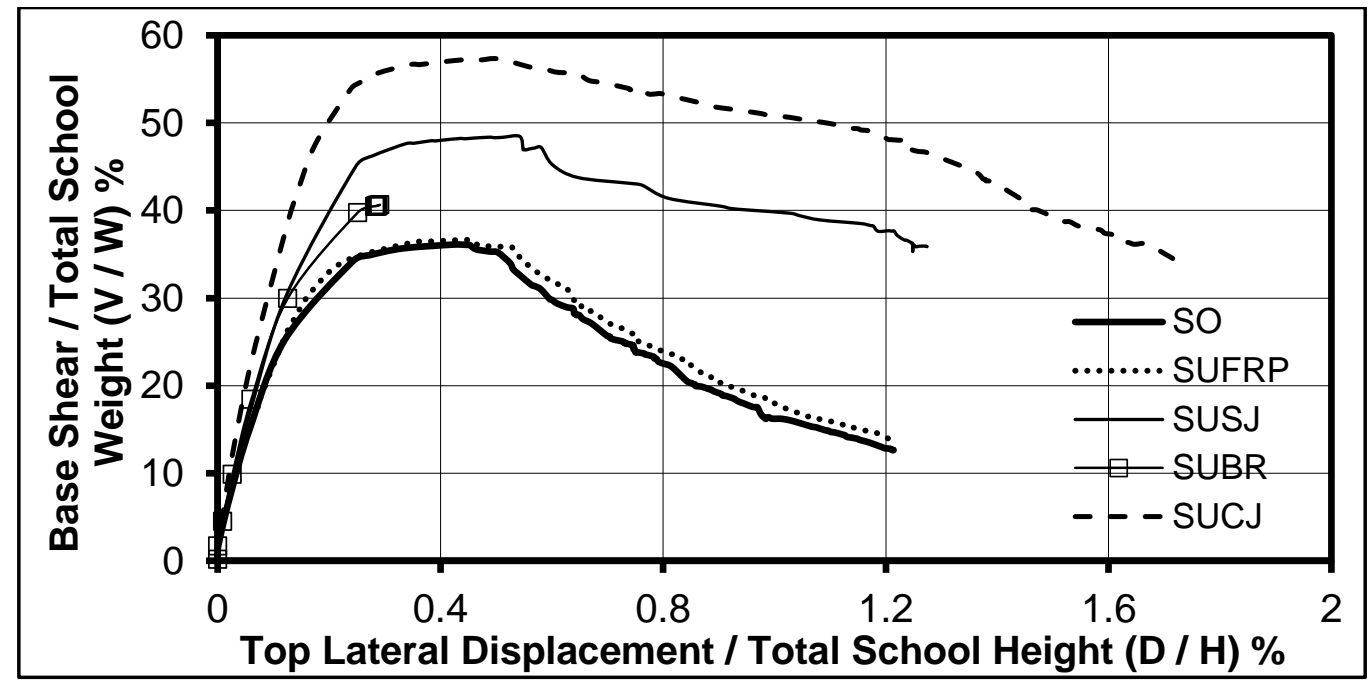

Figure 7- Capacity Curves Obtained from Pushover Analysis

Table 5.0: Base Shear for the Investigated School from Pushover Analysis

\begin{tabular}{|c|c|c|}
\hline Building & $\begin{array}{c}\text { Maximum Base Shear/Total } \\
\text { School Weight } \\
(\% \text { Max. V/W) }\end{array}$ & $\begin{array}{c}\text { \% increase in Max. Base } \\
\text { Shear/Total School Weight } \\
\text { (Max. (V/W }\end{array}$ \\
\hline SO & 36.11 & - \\
\hline SUFRP & 36.65 & 1.50 \\
\hline SUSJ & 48.45 & 34.17 \\
\hline SUBR & 40.65 & 58.65 \\
\hline SUCJ & 57.29 & \\
\hline
\end{tabular}

Table 6.0: Seismic Parameters for the Investigated School from Pushover Analysis

\begin{tabular}{|c|c|c|c|c|c|c|c|c|c|c|c|}
\hline Building & $\begin{array}{c}\mathbf{s}^{\Delta} \\
(\mathbf{c m})\end{array}$ & $\begin{array}{c}y^{\Delta} \Delta \\
(\mathbf{c m})\end{array}$ & $\begin{array}{l}\max \Delta \\
(\mathbf{c m})\end{array}$ & $\begin{array}{c}\mathrm{s} V \\
(\mathrm{kN})\end{array}$ & $\begin{array}{c}\mathbf{y} \\
(\mathbf{k N})\end{array}$ & $\begin{array}{l}\max V \\
(\mathbf{k N})\end{array}$ & $\boldsymbol{\Omega}$ & ${ }_{s} \mu$ & $\begin{array}{c}\mathrm{eu} V \\
(\mathbf{k N})\end{array}$ & ${ }_{\mu} \mathbf{R}$ & $\mathbf{Q}$ \\
\hline SO & 1.81 & 2.5 & 18.21 & 8500 & 12190 & 12190 & 1.43 & 7.28 & 28500 & 2.34 & 5.0 \\
\hline SUFRP & 1.81 & 2.5 & 18.23 & 8800 & 12378 & 12378 & 1.41 & 7.29 & 31000 & 2.50 & 5.3 \\
\hline SUSJ & 1.85 & 2.4 & 19.1 & 10500 & 16364 & 16364 & 1.56 & 7.96 & 39000 & 2.38 & 5.6 \\
\hline SUBR & 1.89 & 2.0 & 4.37 & 10100 & 13730 & 13730 & 1.36 & 2.19 & 29000 & 2.11 & 4.3 \\
\hline SUCJ & 1.91 & 2.3 & 25.73 & 14500 & 19351 & 19351 & 1.33 & 11.19 & 60000 & 3.10 & 6.2 \\
\hline
\end{tabular}

Note: 1 -The design allowable stress factor $(\gamma)$ is taken equal to 1.5 for the calculation of the q-factor. $2-\Delta_{\mathrm{S}}$ is the drift at first yield.

$$
{ }_{\mathrm{y}} \mathrm{V} /{ }_{\text {eu }} \mathrm{V}={ }_{\mu} \mathrm{R}-3
$$




\section{B-Nonlinear Dynamic (Time History) Analysis:}

To study the seismic performance of the school and its four upgrading systems, nonlinear time-history analysis is made utilizing three scaled natural seismic records. The earthquakes are applied in the short direction and 0.3 of their values in the long direction. As shown in Table 7.0, the value of the maximum interstorey drift divided by the storey height obtained when applying the three scaled earthquakes are almost the same for the original school (SO) and for the seismic upgrading methods SUFRP and SUCJ. For example, the value of the maximum interstorey drift/story height when applying earthquake 1 is $1.27 * 10^{-3}$ for schools SO, $1.3 * 10^{-3}$ for school SUFRP, and $1.33 * 10^{-3}$ for school SUCJ. Upgrading methods SUSJ and SUBR generally resulted in reduction of the maximum interstory drift when compared to the original school (SO). For example, for the 1st earthquake, school SUSJ gives maximum interstorey drift divided by storey height equals $0.9 * 10^{-3}$. The same record for school SUBR is $0.9 * 10^{-3}$. Both of which are smaller than the $1.27 * 10^{-3}$ associated with school SO. However, the value of maximum top storey drift/ total school height $\left(\mathrm{D}_{\mathrm{T}} / \mathrm{H}_{\mathrm{T}}\right)$ showed reduction for each of the three applied earthquakes comparing schools SUSJ and SUBR to school SO as shown in Table 8.0. For example, applying earthquake 1 gives $\mathrm{D}_{\mathrm{T}} / \mathrm{H}_{\mathrm{T}}$ equals $1.0 * 10^{-3}, 0.8 * 10^{-3}$, and $0.77 * 10^{-3}$ for schools SO, SUSJ, and SUBR, respectively. As shown in Table 8.0, the change in the base shear was small with the exception of school SUCJ which showed large increase in the base shear. In the case of earthquake 1 , the values of $\mathrm{V} / \mathrm{W} \%$ are 21.92 for school SO and 34.87 for school SUCJ.

Table 7.0: Maximum Interstorey Drift/ Storey Height (Inter-Story Drift Ratio) for the Investigated School from Nonlinear Dynamic Analysis

\begin{tabular}{|c|c|c|c|c|}
\hline \multirow[t]{2}{*}{$\begin{array}{l}\text {-Build } \\
\text { ing }\end{array}$} & \multirow{2}{*}{$\begin{array}{l}\text { Floor } \\
\text { with } \\
\text { Max- } \\
\text { imum } \\
\text { Value }\end{array}$} & \multicolumn{3}{|c|}{$\begin{array}{l}\text { Scaled Earthquake Natural } \\
\text { Record }\end{array}$} \\
\hline & & 1 & 2 & 3 \\
\hline $\mathrm{SO}$ & $\mathrm{rd}_{3}$ & $1.3^{*^{3-}} 10$ & ${ }^{3-} 10 * 1.17$ & ${ }^{3-} 10 * 1.7$ \\
\hline \multirow[t]{2}{*}{ SUFRP } & $\begin{array}{ll}\mathrm{nd}^{2} \\
2\end{array}$ & - & - & $3-10 * 1.7$ \\
\hline & $\mathrm{rd}_{3}$ & ${ }^{3-} 10 * 1.3$ & ${ }^{3-} 10 * 1.13$ & ${ }^{3-} 10 * 1.7$ \\
\hline \multirow[t]{3}{*}{ SUSJ } & $\mathrm{nd}_{2}$ & - & - & ${ }^{3-} 210 * .1$ \\
\hline & $\mathrm{rd}_{3}$ & ${ }^{3-} 10 * 0.9$ & ${ }^{3-} 10 * 1.17$ & ${ }^{3-} 210 * .1$ \\
\hline & th 4 & ${ }^{3-} 10 * 0.9$ & - & - \\
\hline \multirow[t]{2}{*}{ SUBR } & ${ }^{n d} 2$ & - & - & ${ }^{3-} 110 * .1$ \\
\hline & $\mathrm{rd}_{3}$ & ${ }^{3-} 10 * 0.9$ & $3-10 * 1.17$ & - \\
\hline \multirow[t]{2}{*}{ SUCJ } & $\mathrm{nd}_{2}$ & ${ }^{3-} 10 * 1.3$ & - & - \\
\hline & $\mathrm{rd}_{3}$ & ${ }^{3-} 10 * 1.3$ & $3-10 * 1.30$ & ${ }^{3-} 010 * .1$ \\
\hline
\end{tabular}

Table 8.0: Maximum Top Storey Drift/ Total School Height $\left(\mathrm{D}_{\mathrm{T}} / \mathrm{H}_{\mathrm{T}}\right)$ (Total Displacement Ratio) and Base Shear/ Total School Weight (V/W\%) for the Investigated School from Nonlinear Dynamic Analysis

\begin{tabular}{|c|c|c|c|c|}
\hline \multirow[t]{2}{*}{ Building } & & \multicolumn{3}{|c|}{$\begin{array}{c}\text { Scaled Earthquake Natural } \\
\text { Record }\end{array}$} \\
\hline & & 1 & 2 & 3 \\
\hline \multirow[t]{2}{*}{$\mathrm{SO}$} & ${ }_{\mathrm{T}} \mathrm{H} / \mathrm{T}_{\mathrm{T}} \mathrm{D}$ & $* 1.0^{3-} 10$ & $\underset{3}{0.99 *^{-1} 10}$ & $1.5 *^{3-} 10$ \\
\hline & $\% \mathrm{~V} / \mathrm{W}$ & 21.92 & 17.89 & 26.05 \\
\hline \multirow[t]{2}{*}{ SUFRP } & ${ }_{\mathrm{T}} \mathrm{H} /{ }_{\mathrm{T}} \mathrm{D}$ & ${ }^{3-} 10 * 1.1$ & $0.93 *^{-} 10$ & $1.4 *^{3-} 10$ \\
\hline & $\% \mathrm{~V} / \mathrm{W}$ & 19.81 & 18.75 & 27.18 \\
\hline \multirow[t]{2}{*}{ SUSJ } & ${ }_{\mathrm{T}} \mathrm{H} / \mathrm{T}_{\mathrm{T}} \mathrm{D}$ & ${ }^{3-} 10 * 0.8$ & $\underset{3}{0.99 *^{-} 10}$ & $\begin{array}{c}0.97 *^{-} 10 \\
\end{array}$ \\
\hline & $\% \mathrm{~V} / \mathrm{W}$ & 20.52 & 23.68 & 24.41 \\
\hline \multirow[t]{2}{*}{ SUBR } & ${ }_{\mathrm{T}} \mathrm{H} / \mathrm{T}_{\mathrm{T}} \mathrm{D}$ & $0.8 * 10^{-3}$ & $\begin{array}{c}0.99 * 10^{-} \\
3\end{array}$ & $\underset{3}{0.90 * 10^{-}}$ \\
\hline & V/W\% & 17.57 & 20.81 & 21.88 \\
\hline \multirow[t]{2}{*}{ SUCJ } & $\mathrm{D}_{\mathrm{T}} / \mathrm{H}_{\mathrm{T}}$ & $1.1 * 10^{-3}$ & $1.10_{3}+10^{-}$ & $\begin{array}{c}0.80_{*} 10^{-} \\
-\end{array}$ \\
\hline & V/W\% & 34.87 & 29.60 & 25.68 \\
\hline
\end{tabular}

\section{Conclusions}

1-Using bracings for the school (SUBR) resulted in reducing both the failure top level displacement/total height and interstorey drift/storey height.

2-The FRP jacket (SUFRP), the steel jacket (SUSJ), and the concrete jacket (SUCJ) give higher value for the failure top level displacement/total height and interstorey drift/storey height. However, the failure loads are higher for the upgraded schools.

3-Seismic upgraded schools SUFRP, SUSJ, and SUCJ show better translation ductility compared to the original school as evident from the capacity curves and seismic parameters.

4-Seismic upgraded school SUBR gives lower translation ductility.

5-All the upgrading methods result in increase of the base shear. The maximum recorded increase is for SUCJ.

6-As evident from the seismic parameters, schools SUFRP, SUSJ, and SUCJ dissipate more seismic energy compared to school SUBR.

7-The nonlinear dynamic analysis gives generally lesser maximum interstorey drift/storey height for upgraded schools SUSJ and SUBR compared to the original school SO.

8-For schools SUFRP and SUCJ almost similar value to school SO for the maximum interstorey drift/storey height is obtained from the nonlinear dynamic analysis.

9-As obtained from the pushover analysis, the nonlinear time history analysis gives almost similar 
values for the base shear for the four seismic upgraded schools compared to the original school with the maximum increase for SUCJ.

10-In summary, the upgrading method using bracing is good in limiting the drift while the upgrading method using concrete jacket gives better ductility.

\section{References}

[1] Adhikari, A., Rao, K. R. M., Gautam, D., and Chaulagain, H.; "Seismic Vulnerability and Retrofitting Scheme for Low-to-Medium Rise Reinforced Concrete Buildings in Nepal", Journal of Building Engineering. V. 21, 2019, pp. 186-199.

[2] Almeida, A., Ferreira, R., Proenca, J. M., and Gago, A. S.; "Seismic Retrofit of RC Building Structures with Buckling Restrained Braces", Engineering Structures, V. 130, 2017, pp. 14-22, 2017.

[3] Choi, S. W., Kim, Y., and Park, H. S.; "MultiObjective Seismic Retrofit Method for Using FRP Jackets in Shear-Critical Reinforced Concrete Frames", Composites: Part B, V. 56, 2014, pp. $207-$ 216.

[4] Elbetar, S., and Issa, M. S.; "Seismic Retrofit of Existing Reinforced Concrete Framed Buildings", Building Engineer, 92(7), July 2017, pp. 32-35.

[5] Gandelli, E., Taras, A., Distl, J., and Quaglini, V.; "Seismic Retrofit of Hospitals by Means of Hysteretic Braces: Influence on AccelerationSensitive Non-structural Components", Frontiers in Built Environment. V. 5, Article 100, August 2019, pp. 1-10.

[6] Griffith, M. C., and Pinto, A. V.; "Seismic Retrofit of Reinforced Concrete Buildings- A Review and Case Study", 12 WCEE 2000 Conference, Article No. 2327, 2000, pp. 1-8.

[7] Issa, M. S., and Issa, H. M.; "Application of Pushover Analysis for the Calculation of Behavior Factor for Reinforced Concrete Moment-Resisting Frames", International Journal of Civil and Structural Engineering, 5(3), 2015, pp. 216-226.
[8] Issa, M. S., and Taha, N. A. A.; "Assessment of Bracing Systems for Seismic Enhancement of Reinforced Concrete Frames", $2^{\text {nd }}$ International Conference on Bridge Testing, Monitoring \& Assessment, Article GEN15a, December 2015, Cairo, Egypt.

[9] Maheri, M. R.; "Recent Advances in Seismic Retrofit of RC Frames", Asian Journal of Civil Engineering (Building and Housing), 6(5), 2005, pp. 373-391.

[10] Mander, J. B., Priestly, M. J. N., and Park, R.; "Theoretical Stress-Strain Model for Confined Concrete", Journal of Structural Engineering, 114(8), 1988, pp. 1804-1826.

[11] Martinez-Rueda, J. E., and Elnashai, A. S., "Confined Concrete Model under Cyclic Load", Materials and Structures, 30(197), 1997, pp. 139-147. [12] Porcu, M. C., Vielma, J. C., Panu, F., Aguilar, C., and Curreli, G.; "Seismic Retrofit of Existing Buildings Led by Non-Linear Dynamic Analyses", International Journal of Safety and Security Engineering, 9(3), 2019, pp. 201-212.

[13] Rodriguez, M., Meeri, M., and Park, R.; "Repair and Strengthening of Reinforced Concrete Buildings for Seismic Resistance", Earthquake Spectra, 7(3), 1991, pp. 439-459.

[14] Sarno, L. D., and Manfredi, G.; "Seismic Retrofitting with Buckling Restrained Braces: Application to an Existing Non-Ductile RC Framed Building", Soil Dynamics and Earthquake Engineering, V. 30, 2010, pp. 1279-1297.

[15] SeismoSoft; "SeismoStruct - a Computer Program for Static and Dynamic Nonlinear Analysis of Framed Structures", Report Available on line at URL: http://www.seismosoft.com, 2014.

[16] Thermou, G. E., and Elnashai, A. S.; "Seismic Retrofit Schemes for RC Structures and Local-Global Consequences", Earthquake Engineering and Structural Dynamics, V. 8, 2006, pp. 1-15, 2006. 